\title{
PROTECTIVE EFFECTS OF CURCUMA LONGA (TURMERIC) ON METHOTREXATE INDUCED MORPHOLOGICAL CHANGES IN THE LIVER OF ALBINO MICE.
}

\footnotetext{
1. MBBS, MPhil (Anatomy) Assistant Professor Pak International Medical College Peshawar

2. MBBS, MPhil (Anatomy), MHPE Associate Professor Rehman College of Dentistry Peshawar

3. MBBS, MPhil (Anatomy), MPH Associate Professor Rehman College of Dentistry Peshawar

4. MBBS, MPhil (Anatomy) Assistant Professor Khyber Medical College, Peshawar

5. MBBS, MPhil (Anatomy) Assistant Professor Khyber Medical College, Peshawa

6. MBBS, MPhil (Anatomy) Senior Lecturer North West School of Medicine Peshawa
}

Correspondence Address:

Dr. Nazish Waheed

Associate Professor

Rehman College of Dentistry

Peshawar

nazishnabeel@hotmail.com

Article received on:

19/08/2019

Accepted for publication: 20/10/2019
Farah Deeba', Nazish Waheed², Qazi Waheed Ullah'3 ${ }^{3}$, Shazia Iftikhar ${ }^{4}$, Zainab Rehman ${ }^{5}$, Irum Javaid

ABSTRACT... Drugs induced liver injury is a major health problem. ${ }^{1}$ Methotrexate which is antagonist of folic acid is used to treat different types of neoplasms, rheumatoid arthritis and psoriasis. ${ }^{2}$ The therapeutic applications of Methotrexate is usually limited by its severe Hepatotoxicity. Herbs play important role for the treatment of various liver diseases. ${ }^{3}$ Turmeric (Curcuma Longa L, zingiberaceae) is used to treat cancer, inflammatory disorders, hepatitis and other liver disorders, skin diseases, Alzheimer's disease, rheumatoid arthritis. ${ }^{4}$ Study Design: Laboratory based randomized controlled trial. Setting: Animal House of IBMS (Institute of Basic Medical Science), by the permission of Ethical Committee of (KMU) Khyber Medical University Hayatabad Peshawar. Period: March to September 2018. Material \& Methods. 28 adult male albino mice were divided into control Group A and experimental Groups B,C and D. Group B was given Turmeric extract per oral $(400 \mathrm{mg} / \mathrm{kg}$ ) daily for 14 days. Group $\mathrm{C}$ was given Injection Methotrexate $(40 \mathrm{mg} / \mathrm{kg})$ intraperitoneally (I.P) on day 7. Group D was given Turmeric extract per oral $(400 \mathrm{mg} / \mathrm{kg}$ ) daily for 7 days as pre administration to injection Methotrexate and on day 7 injection Methotrexate $(40 \mathrm{mg} / \mathrm{kg}$ ) was given intraperitoneally (I.P) and Turmeric extract per oral $(400 \mathrm{mg} / \mathrm{kg})$ was given daily for further 7 days as post administration to injection Methotrexate. Histological slides were prepared to see the effects of Turmeric plus Methotrexate on diameter of central vein and congestion in central vein. Results: The histological examination of liver sections of control group. A showed normal appearance of central vein. In Turmeric treated group (Group B) also no obvious histological changes were observed. Examination of liver tissue of Group C (Methotrexate group) showed severe histological changes which include dilation and congestion of central vein. Group D (Methotrexate + Turmeric group) showed significant reduction in dilation and congestion of central vein. Conclusion: This study is in accordance with other studies in which different types of herbals showed protective effects on Methotrexate induced liver damage.

Key Words: Curcuma longa, Central vein congestion, Central vein dilation, Hepatotoxicity.

Article Citation: Deeba F, Waheed N, Waheed Ullah Q, Iftikhar S, Rehman Z, Javaid I. Protective effects of Curcuma Longa (Turmeric) on Methotrexate induced morphological changes in the liver of albino mice. Professional Med J 2019; 26(12):2246-2249. DOI: 10.29309/TPMJ/2019.26.12.4056

\section{Introduction}

One of the major health problems faced by the health care professionals, pharmaceutical industry and drug regulatory agencies is liver injury induced by the drugs. ${ }^{5}$ More than nine hundred medicines and toxin have been reported to induce liver damage. ${ }^{6}$ Methotrexate which is hepatotoxic drug is used to treat different types of neoplasms. It is also used to treat inflammatory conditions such as rheumatoid arthritis and psoriasis. ${ }^{7}$ In many autoimmune diseases such as pamphigus, uveitis and myasthenia gravis it is used as a first line drug. Therefore inspite of documented proofs that it can cause liver damage, a large number of patients are using this drug. ${ }^{8}$ Methotrexate inhibit dihydrofolate reductase an enzyme which is essential for the synthesis of tetrahydrofolate. ${ }^{9}$ For the nucleoside thymidine denovo synthesis, folic acid is needed. So the synthesis of thymidilate is indirectly affected by the Methotrexate which is essential for the synthesis of DNA. ${ }^{10}$ For neutralizing reactive oxygen species glutathione reductase enzyme use cytosolic antioxidant NADP which is inhibited by Methotrexate, decreases glutathione level, thus hepatocytes become damaged by the 
reactive oxygen molecules such as hypochloride radicals, superoxide, hydroxyl radicals and hydrogen peroxide. ${ }^{11}$

In allopathic medical practices no reliable drugs are available which provides protection to the liver so herbs play important role for the treatment of various liver diseases. ${ }^{12} \mathrm{~A}$ number of reviews are published stating the importance of plant extracts in the diseases of the liver. ${ }^{13}$

Turmeric (Curcuma Longa $L$, zingiberaceae), is a yellow-colored spice derived from the perennial herb, which has been widely used for centuries in traditional therapies for different diseases including cancer,inflammatory disorders, hepatitis and other liver disorders, skin diseases, Alzheimer's disease, rheumatoid arthritis. ${ }^{14}$ Besides curcumin, Turmeric contains more than 300 other components, notably phenolics and terpenoids. ${ }^{15}$

For free radicals Turmeric acts as a scavenger .It also inhibits production of Reactive oxygen species (ROS) like hydrogen peroxide and superoxide anions in vitro study. ${ }^{16}$ In vivo study it also lowers generation of Reactive oxygen species. Thus free radicals induced liver toxicity is protected by Turmeric due to it antioxidant effects. ${ }^{17}$ In the current study, using a mice model, the effects of Turmeric in Methotrexate -induced liver injury, are observed.

\section{MATERIAL AND METHODS}

This laboratory based randomized controlled trial was carried out at Animal House of IBMS (Institute of Basic Medical Science), from March to September 2018 by the permission of Ethical Committee of (KMU) Khyber Medical University Hayatabad Peshawar. 28 adult male albino mice (5 to 7 weeks) weighing 25 to 40 grams were kept in 12 hours/light 12 hours/dark cycle at a temperature of $20_{ \pm} \mathrm{C}$ and were acclimatized for two weeks 28 adult male albino mice were divided into control Group A and experimental Groups, B, C and D. In Group A4 mice, and in Group B, C and D 08 mice were included. No drug was given to group A. Group B was given Turmeric extract per oral $(400 \mathrm{mg} / \mathrm{kg}$ ) daily for 14 days. Group C was given Injection Methrotrexate $(40 \mathrm{mg} / \mathrm{kg})$ intraperitoneally (I.P) on day 7. Group D was given Turmeric extract per oral $(400 \mathrm{mg} / \mathrm{kg}$ ) daily for 7 days as pre administration to injection Methotrexate and on day 7 injection Methrotrexate $(40 \mathrm{mg} / \mathrm{kg})$ was given intraperitoneally (I.P) and Turmeric extract per oral $(400 \mathrm{mg} / \mathrm{kg}$ ) was given daily for further 7 days as post administration to injection Methotrexate.

All the animals were sacrificed on day 14 . The liver was removed and preserved in formalin. Different sections of the liver were prepared by tissue processing. Eosin and Haematoxyline stain was applied. Tissues were observed under light microscope to study the histological parameters. Data was analyzed using SPSS version 21 . The arithmetic means of observation was calculated. Standard deviation (SD) was calculated. According to result and variable, statistical significance was analyzed using Anovo test and Chi square test. $P$ value $<.05$ was considered as statistically significant

\section{RESULTS}

\section{Changes in diameter of central vein (Figure 1 and 2)}

In this study analysis of diameter of central vein was done. Increase in diameter of central vein between groupswas observed by theapplication of ANOVA test. The Methotrexate (Group C) showed a significant increase in the diameter of central vein with $p$ value of 0.00 . In the Methotrexate plus Turmeric (Group D) the diameter was increased as compared to control and Turmeric (Group B) but when (Group D) was compared to Group C, It was noted that the dilatation in (Group D) showed23cx slight decrease.

\section{Congestion in central vein (figure 1 and 2)}

Chi square test shows significant increase in central vein congestion in Methotrexate (Group C) and Methotrexate plus Turmeric (Group D) as compared to control and Turmeric (Group B) with a $p$ value of 0.00 . Whereas significant decrease in central vein congestion in Methotrexate + Turmeric (Group D) than Methotrexate (Group C). 


\begin{tabular}{|c|c|c|c|}
\hline $\begin{array}{c}\text { Mean } \pm \text { SD of } \\
\text { control group A } \\
\text { (um) }\end{array}$ & $\begin{array}{c}\text { Test } \\
\text { groups }\end{array}$ & $\begin{array}{c}\text { Diameter After } \\
\text { Treatment } \\
\text { Mean } \pm \text { SD } \\
\text { (um) }\end{array}$ & P-Value \\
\hline $7.18 \pm .1807$ & Group B & $7.27 \pm .2314$ & 0.00 \\
\hline & Group C & $17.2 \pm .3162$ & 0.00 \\
\hline & Group D & $11.1 \pm .2187$ & 0.00 \\
\hline
\end{tabular}

Table-I. Shows the effects of Methotrexate and Turmeric on dilatation of central vein of mice liver.

\begin{tabular}{|c|c|c|c|c|c|}
\hline & $\begin{array}{c}\text { Control } \\
\text { Parameter } \\
\text { group A } \\
\mathbf{n = 8}\end{array}$ & $\begin{array}{c}\text { Turmeric } \\
\text { group B } \\
\mathbf{n = 8}\end{array}$ & $\begin{array}{c}\text { Metho- } \\
\text { trexate } \\
\text { group C } \\
\mathbf{n = 8}\end{array}$ & $\begin{array}{c}\text { Metho- } \\
\text { trexate } \\
\text { plus } \\
\text { Turmeric } \\
\text { group D } \\
\mathbf{n = 8}\end{array}$ & $\begin{array}{c}\text { P- } \\
\text { Value }\end{array}$ \\
\hline $\begin{array}{c}\text { Congestion } \\
\text { in central } \\
\text { vein }\end{array}$ & $\begin{array}{c}\text { Absent } \\
\mathrm{n}=8\end{array}$ & $\begin{array}{c}\text { Absent } \\
\mathrm{n}=8\end{array}$ & $\begin{array}{c}\text { marked } \\
\mathrm{n}=8\end{array}$ & $\begin{array}{c}\text { Mild to } \\
\text { moderate } \\
n=8\end{array}$ & 0.00 \\
\hline
\end{tabular}

Table-II. The effect of Methotrexate and Turmeric on congestion in central vein

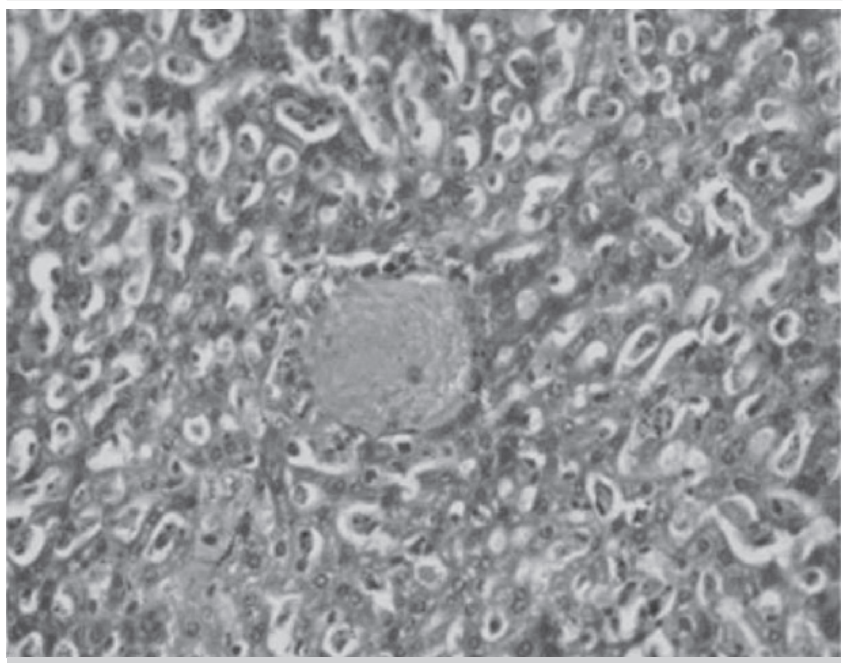

Figure-I. Photomicrograph of liver of (MTX Group C) Where " $A$ " shows severe congestion in central vein at $40 x$.

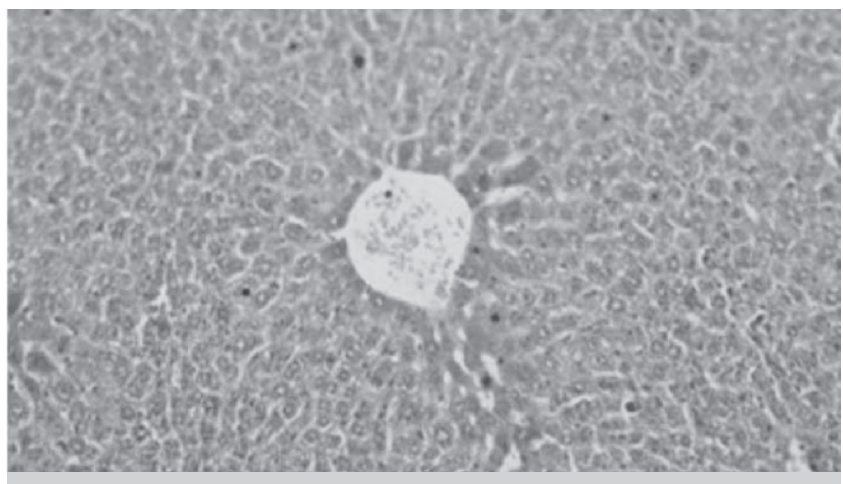

Figure-II. Photomicrograph of liver of

(MTX + Turmeric Group D) Where "B" shows mild congestion in central vein at $40 x$.

\section{DISCUSSION}

Results of this study showed prominent histological changes in the liver tissue of animals treated with Methotrexate. Increase in diameter of central vein was observed in Methotrexate group. Significant reduction in central vein diameter occur due to the administration of ethanolic extract of Curcuma Longa (Turmeric) to all animals of Methotrexate plus Turmeric group. These finding correlate with the finding of Adel Rezaei Moghadam who also observed that Methotrexate caused significant increase in central vein diameter and ethanolic extract of Curcuma Longa (Turmeric) caused significant reduction in diameter of central vein99. ${ }^{18}$ In all animals of Methotrexate group congestion in central vein was observed in this study. Central vein congestion is the result of toxic effects of Methotrexate. Congestion in central vein happens because of obstruction to hepatic outflow or inflow. ${ }^{19}$ When ethanolic extract of Curcuma Longa (Turmeric) was given to all animals of Methotrexate plus Turmeric group moderate reduction in congestion of central vein was observed. This shows protective effect of Curcuma Longa on Methotrexate induced hepatic damage. Our results are in correlation with the results of Ehab Tousson et al. In his study L-carnitine showed significant reduction in congestion of central vein induced by Methotrexate. ${ }^{20}$

\section{CONCLUSION}

In conclusion this study demonstrates clearly that administration of Curcuma Longa (Turmeric) protected hepatic tissue due to its antioxidant activity and it might have a capability to be used in the treatment regimen in future.

\section{Copyright $(20$ Oct, 2019.}

\section{REFERENCES:}

1. Yuan L, Kaplowitz N. Mechanisms of drug-induced liver injury. Clinics in liver disease. 2013;17(4):507-18.

2. Grosflam J, Weinblatt ME. Methotrexate: mechanism of action, pharmacokinetics, clinical indications, and toxicity. Current opinion in rheumatology. 1991;3(3):363-8. 
3. Jain S, Tekade A, Joshi U, Kale R, Purohit R. Protective effect of Gingko biloba on antitubercular drugs induced hepatotoxicity in rats. Indian drugs. 2005;42(3):167-71.

4. Chattopadhyay I, Biswas K, Bandyopadhyay U, Banerjee RK. Turmeric and curcumin: Biological actions and medicinal applications. CURRENT SCIENCE-BANGALORE-. 2004;87:44-53.

5. Lee WM. Drug-induced hepatotoxicity. New England Journal of Medicine. 2003;349(5):474-85.

6. Panqueva RdPL. Morphological issues of drug induced liver disease. Rev Col Gastroenterol. 2014;29(4):439-50.

7. Tugwell P, Bennett K, Gent M. Methotrexate in rheumatoid arthritis: indications, contraindications, efficacy, and safety. Annals of internal medicine. 1987;107(3):358-66.

8. Tripathi KD. Essentials of medical pharmacology. JP Medical Ltd; 2013 Sep 30.

9. Tian $\mathrm{H}$, Cronstein $\mathrm{BN}$. Understanding the mechanisms of action of methotrexate. Bull NYU Hosp Jt Dis. 2007 Oct 1;65(3):168-73.

10. Biernat J, Sendur R, Pawlik W, Brzozowski T. Dual role of sensory neuropeptides in methotrexateinduced liver damage. Gastroenterologia Polska/ Gastroenterology. 2010 May 1;17(3).

11. Jahovic N, Çevik $H$, Şehirli AÖ, Yeğen BÇ, Şener G. Melatonin prevents methotrexate $\square$ induced hepatorenal oxidative injury in rats. Journal of pineal research. 2003;34(4):282-7.

12. Jain SP, Tekade AR, Joshi UM, Kale RH, Purohit RN. Protective effect of Gingko biloba on antitubercular drugs induced hepatotoxicity in rats. Indian drugs. 2005;42(3):167-71.
13. Ahsan MR, Islam KM, Bulbul IJ, Musaddik MA, Haque E. Hepatoprotective activity of methanol extract of some medicinal plants against carbon tetrachlorideinduced hepatotoxicity in rats. Eur $J$ Sci Res. 2009;37(2):302-10.

14. Chattopadhyay I, Biswas K, Bandyopadhyay U, Banerjee RK. Turmeric and cur cumin: Biological actions and medicinal applications. Current science-bangalore-. 2004 Jul 10;87:44-53.

15. Li S, Yuan W, Deng G, Wang P, Yang P, Aggarwal B. Chemical composition and product quality control of turmeric (Curcuma longa L.)

16. Panpatil VV, Tattari S, Kota N, Nimgulkar C, Polasa K. In vitro evaluation on antioxidant and antimicrobial activity of spice extracts of ginger, turmeric and garlic. J. Pharmacogn. Phytochem.. 2013;2:143-8.

17. Thakur R,Yadav K,Khadka KB study of antioxidant , antibacterial and anti-inflammatory activity of cinnamon (cinamonum tamala) ginger,(zingiber officinale) and turmeric(curcuma longa). American journal of life sciences .2013; 1(6): 273-277.

18. Moghadam AR, Tutunchi S, Namvaran-Abbas-Abad A, Yazdi M, Bonyadi F, Mohajeri D, Mazani M, Marzban H, Łos MJ, Ghavami S. Pre-administration of turmeric prevents methotrexate-induced liver toxicity and oxidative stress. BMC complementary and alternative medicine. 2015 Dec;15(1):246.

19. Gore RM, Mathieu DG, White EM, Ghahremani GG, Panella JS, Rochester D. Passive hepatic congestion: cross-sectional imaging features. AJR. American journal of roentgenology. 1994 Jan;162(1):71-5.

20. Tousson E, Zaki ZT, Abu-Shaeir WA, Hassan H. Methotrexate-induced hepatic and renal toxicity: role of L-carnitine in treatment. Biomed Biotechnol. 2014;2(4):85-92.

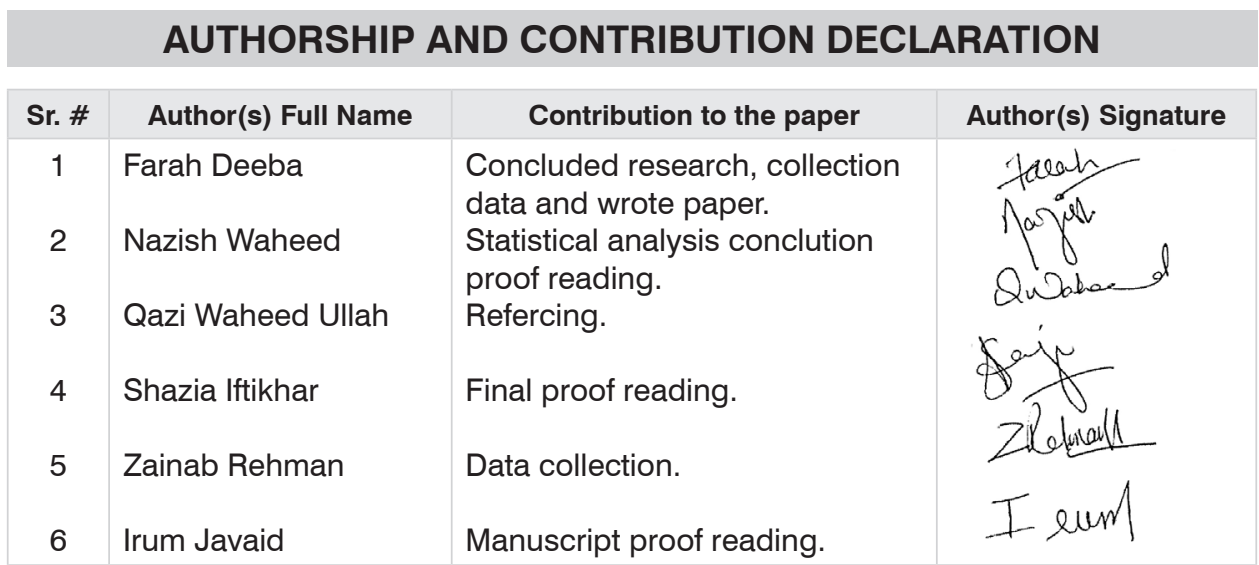

